\title{
ABHILLANI ABHA': KOREOGRAFI YANG TERILHAMI DARI NILAI HARGA DIRI DI MADURA
}

\author{
Oleh : Fatmawati Sugiono Putri; M. Heni Winahyuningsih; Darmawan Dadijono \\ Jurusan Tari, Fakultas Seni Pertunjukan, Institut Seni Indonesia Yogyakarta \\ E-mail: fatmaputri045@gmail.com; heniwie@yahoo.com; darmawandadijono@gmail.com
}

\section{RINGKASAN}

Abhillani Abha' merupakan judul karya penciptaan tari Abhillani merupakan istilah bahasa Madura yang berarti membela, dan $A b h a^{\prime}$ merupakan istilah bahasa Madura yang berarti diri (harga diri). Karya ini bersumber dari kebiasaan masyarakat Madura khususnya di daerah Bangkalan, dengan kasus carok yang dilakukan oleh laki-laki untuk melindungi atau mempertahankan harga dirinya. Secara signifikan carok dijadikan sumber materi dramatik dan sumber materi artistik pada penciptaan karya tari ini. Pelecehan dijadikan tema pada penciptaan karya tari. Berangkat dari pengalaman menyaksikan peristiwa carok, dan mengamati gerak pelaku carok dalam melakukan gerak silat serta ketrampilannya memainkan clurit, memicu ide gagasan dan ide kinestetik dalam proses penciptaan karya tari. Karya Tari ini merupakan karya koreografi kelompok, maka dipilih metode penciptaan tari dengan menggunakan konsep yang diutarakan oleh Jacqueline Smith dalam bukunya Dance Compotitions: A Practical Guide for Teacher (1976), tentang metode konstruksi tari yang terdiri dari 5 tahap, yaitu tahap 1 tentang rangsang awal, tahap 2 tentang memilih motif menjadi komposisi, tahap 3 tentang menjadikan motif menuju komposisi kelompok, tahap 4 tentang bentuk tari, dan tahap 5 tentang elemen konstruksi. Properti celurit, motif Tari jawatimuran (Surabayan, Madura), gerak dasar silat, dan pola iringan jawatimuran (Surabayan, Madura) menjadi bahanbahan untuk melakukan proses kreatif penciptaan Abhillani Abha'.

Kata Kunci : Madura, Carok, Harga Diri.

\section{ABSTRACT}

Abhillani Abha' is the title of a dance creation work. This work originated from the custom of the Madurese community, especially in the Bangkalan area, with the carok case committed by men 
to protect or maintain their dignity. Carok was significantly used as a source of dramatic material and a source of artistic material for the creation of this dance work. Harassment was used as a theme in the creation of dance work. Departing from the experience of witnessing the carok event, and observing the carok actor's movements in performing silat movements and his skills in playing clurit, triggering kinesthetic ideas and ideas in the process of creating dance works.This dance work is a group choreography, then the method of creating dance using the concept expressed by Jacqueline Smith in his book Dance Compotitions: A Practical Guide for Teachers (1976), about the dance construction method consisting of 5 stages, namely stage 1 about excitement beginning, stage 2 about choosing motifs into compositions, stage 3 about making motifs towards group composition, stage 4 about dance forms, and stage 5 about construction elements. The sickle property, the Jawatimuran dance motif (Surabayan, Madura), the basic movements of silat, and the Jawatimuran accompaniment pattern (Surabayan, Madura) became the materials to carry out the creative process of creating Abhillani Abha'.

Keywords: Madura, Carok, Self-Esteem.

\section{PENDAHULUAN}

Sebagai sebuah entitas budaya, suatu kebiasaan yang dilakukan oleh laki-laki Madura bermakna kekhususan - kultural yang tidak serupa dengan etnografi komunitas etnik lain. Tradisi carok sebenarnya ada di keempat kabupaten, hanya saja yang tampak dari sekian kasus carok yang terjadi di Madura yang paling terbanyak di daerah Bangkalan. Kasus carok terjadi disebabkan oleh beberapa hal, yaitu: perebutan tanah atau warisan, irigasi, dan perselingkuhan. Carok selalu dilakukan oleh sesama laki-laki dalam lingkungan orang desa.

Carok pada masyarakat Madura (khususnya Kabupaten Bangkalan) menjadi yang telah beristri, dengan cara melakukan perkelahian atau pertarungan untuk mempertahankan harga dirinya. Tindakan carok ini diawali dengan adanya perselingkuhan seorang istri terhadap suaminya. Setiap bentuk gangguan terhadap istri merupakan pelecehan terhadap harga diri pihak suami dan dianggap merusak tatanan sosial. Gangguan tersebut menimbulkan perasaan malu terutama pada pihak suami, karena peran dan fungsinya melindungi istri dianggap telah gagal (A Latief Wiyata, 2002: 183). Itu sebabnya, martabat dan kehormatan 
istri merupakan manifestasi dari martabat dan kehormatan suami, karena istri adalah bantalla pate (landasan kematian). Kebiasaan carok selain menjadi kebiasaan masyarakat Bangkalan, juga menjadi kesenian tradisi menurut yang dibedakan menurut bentuk, peran, dan fungsinya.

Dalam pemaparan di atas menginspirasi untuk menciptakan karya tari yang bersumber dari kebiasaan masyarakat Madura khususnya di daerah Bangkalan, dengan kasus carok yang dilakukan oleh lakilaki untuk melindungi atau mempertahankan harga dirinya. Selain itu, yang paling signifikan carok dijadikan sumber materi dramatik dan sumber materi artistik pada penciptaan karya tari ini. Sebagai sumber materi dramatik, karena secara mendasar merupakan sumber cerita. Alur terjadinya carok yang diketahui secara mendalam oleh penata menjadi sumber alur dramatik pada penciptaan karya tari ini. Sebagai sumber materi artistik, Carok diambil unsur-unsurnya untuk digarap secara artistik, contohnya: setting, dan tata teknis lampu, penggunaan properti celurit dan ukuran celurit yang akan digunakan dalam ukuran sedang.

\section{PEMBAHASAN}

\section{A. Kerangka Dasar Pemikiran}

Karya ini berbicara tentang adanya pelecehan harga diri yang menimbulkan konflik yang berakibat pada bentuk kekerasan. Melalui sumber ide gagasan dengan adanya pelecehan harga diri, akan dikomposisikan karya tari dengan menggunakan langkahlangkah yang harus dilakukan untuk menghasilkan bentuk karya tari.

Pada penciptaan karya tari ini, akan menggunakan Metode Konstruksi I - V yang digagas atau disampaikan oleh Jacqueline Smith berjudul Dance Composition: A Practical Guide for Teacher (1976), diterjemahkan oleh Ben Suharto, Komposisi Tari: Sebuah Petunjuk Praktis Bagi Guru (1985) untuk menghasilkan sebuah komposisi karya tari, maka ada beberapa aspek tari yang diharapkan dapat mendukung penyampaian karya tari ini.

\section{B. Konsep DasarTari}

1. Rangsang Tari

Koreografi ini menggunakan rangsang visual yang menghasilkan atau diikuti oleh ide gagasan dan rangsang kinestetik. Rangsang visual ini menghasilkan sebuah ide gagasan bagi penata untuk menghasilkan konsep dengan alur dramatik karya. Rangsang kinestetik pada penciptaan karya tari dalam koreografi ini adalah motif dasar gerak silat yang sudah ditransformasikan ke dalam gerak tari, dan motif dasar gerak Jawatimuran (Surabayan, Madura) sebagai acuan dalam ide penggarapan karya tari ini. 


\section{Tema Tari}

Tema atau permasalahan pokok yang disampaikan dalam karya ini, yaitu: pelecehan. Pelecehan ini menjadi penyebab utama timbulnya konflik yang berakibat dengan adanya kekerasan.

3. Judul Tari

Judul tari dalam penciptaan karya koreografi ini adalah Abhillani Abha', diambil dari bahasa sehari-hari dan istilah yang sering disebutkan oleh masyarakat sekitar (Bahasa Madura), Abhillani merupakan istilah bahasa Madura yang berarti membela, dan Abha' merupakan istilah bahasa Madura yang berarti diri (harga diri).

\section{Tipe tari}

Penggarapan karya ini menggunakan tipe tari dramatik, tipe tari dramatik digunakan karena di garapan karya tari ini suasana menjadi hal yang penting dan adanya cerita pesan dan kesan yang ingin disampaikan kepada penonton. Koreografi ini terdiri dari beberapa bagian, yaitu : bagian awal atau introduksi, bagian 1, bagian 2, bagian 3 (klimaks), dan ending.

\section{Konsep Garap Tari}

1. Gerak Tari

Gerak yang akan diwujudkan dalam koroegrafi ini menggunakan gerak dasar Tari jawatimuran (Surabayan, Madura), dan motif dasar gerak silat yang sudah ditransformasikan atau diperindah menjadi gerak tari. Motif dasar gerak silat yang digunakan merupakan bentuk transformasi dari gerak silat yang digunakan untuk bela diri atau olahraga tradisional di daerah setempat, contohnya: gerak tangkis, serang, menghindar, kembangan, nyrewengan, kuda-kuda.

2. Penari

Koreografi ini ditarikan oleh lima penari, yaitu satu penari putri dan empat penari putra. Penggambaran satu penari putri merupakan penyebab terjadinya sebuah konflik yang berakibat kepada bentuk dengan adanya kekerasan. Satu penari putri sebagai simbol harga diri laki-laki, perempuan atau isteri merupakan mahkota laki-laki atau suaminya. Lalu,empat penari putra ini merupakan dua pasangan oposisi yang akan melakukan sebuah carok nantinya. Pada empat penari putra, sesaat akan dilakukan perang atau pertarungan secara nyata dan mengekspresikan keadaan batin orang yang melakukan sebuah pertarungan.

3. Musik Tari

Musik yang digunakan untuk mengiringi koreografi ini adalah gamelan Madura atau Jawa Timur. Laras yang dipakai menggunakan laras slendro dan dominan alat tiup saronin, menggunakan alat perkusi (dugdug atau rebana), dengan kejung atau vocal menggunakan gending atau bahasa Madura 
pada umumnya. Bentuk penyajian iringan dalam koreografi ini mengunakan musik live.

4. Rias dan Busana Tari

Rias dalam koreografi ini penari perempuan menggunakan rias karakter khas Madura pada umumnya. Rias penari puteri dapat mengidentifikasikan bahwa rias tersebut merupakan ciri khas dari rias karakter penari puteri. Ciri rias tersebut diibaratkan cubitan atau garis-garis ala cupang merah di dahi dan leher yang khas memberikan pesona tersendiri. Penari laki-laki menggunakan rias putra gagah yang mendukung karakter yang akan dibawakan. Busana penari putri menggunakan kain yang berbahan dasar kain kebaya warna hitam dan merah diberi aksen warna gold. Bagian bawah memakai celana yang dibuat seperti rok jika tampak depan, jarik dengan motif khas Madura (jarik lasem motif pesisiran). Busana atasan penari putera menggunakan bahan katun warna maroon dan perpaduan jarik Madura (jarik lasem motif pesisiran), bawahannya berbentuk celana dengan model komprang atau lebar dengan berbahas dasar jarik Madura (jarik lasem motif pesisiran). Hiasan kepala penari puteri, menggunakan bunga merah di bagian sanggul bawah dan melati yang menggambarkan keanggunan wanita Madura. Penari putera menggunakan udeng kain yang dimodifikasi dengan gaya jawatimuran.

\section{Pemanggungan}

Koreografi ini dipentaskan di stage Tari, Fakultas Seni Pertunjukan, Institut Seni Indonesia Yogyakarta. Lokasi pementasan di Auditorium atau panggung Jurusan Tari dengan konsep tata cahaya yang akan dilakukan pada komposisi pencahayaan sesuai suasana. Menggunakan trap 2X1 berjumlah 1, trap 1X1 berjumlah 1, trap $50 \mathrm{~cm}$ berjumlah 1 , dan menggunakan siluet, ada beberapa bagian menggunakan buka tutup backdrop.

\section{PROSES PENCIPTAAN TARI}

\section{A. Metode Penciptaan}

Metode atau cara kerja yang digunakan pada penciptaan karya tari ini yang digunakan dalam proses, yaitu Buku yang ditulis oleh Jacqueline Smith berjudul Dance Composition: A Practical Guide for Teacher (1976), diterjemahkan oleh Ben Suharto, Komposisi Tari: Sebuah Petunjuk Praktis Bagi Guru (1985), Metode Konstruksi I sampai Metode Konstruksi V. Tahap yang digunakan untuk mendukung metode konstruksi I - V yang berupa eksplorasi, improvisasi, komposisi, evaluasi menggunakan buku yang ditulis oleh Alma M Hawkins dengan judul Creating Trough Dance, New Jersey: Princeton Book Company (1988) yang dikutip oleh Y. Sumandiyo Hadi dengan judul buku Koreografi Bentuk-Teknik- 
Isi tersebut patut dipahami dan dilalui dengan kesungguhan.

\section{B. Tahapan Penciptaan dan Realisasi} Proses

Koreografi ini terdiri dari beberapa bagian, yaitu: bagian awal atau introduksi, bagian 1, bagian 2, bagian 3 (klimaks), dan ending.

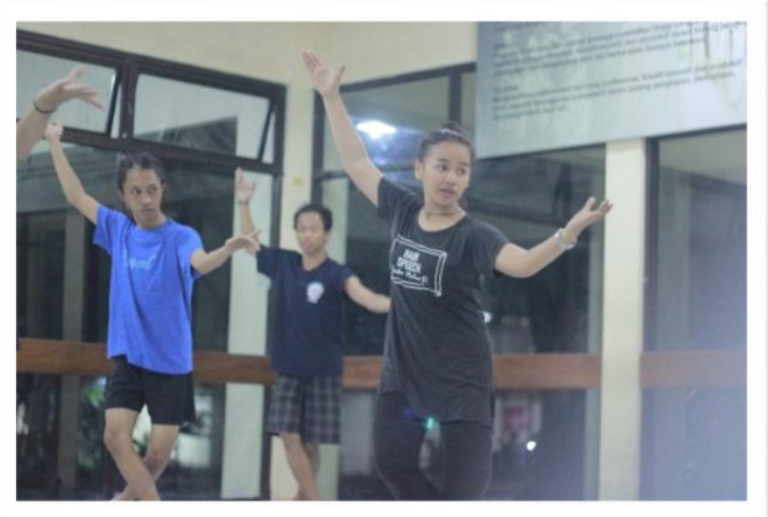

Gambar 01: salah satu pose motif gerak silat pada bagian I

(Foto: Bagus Mahendra, 2020)

1. Bagian Awal atau Introduksi

Pada introduksi yang akan divisualkan yaitu penggambaran penyebab terjadinya carok, yaitu: terjadinya pelecehan tehadap harga diri seorang suami (terjadinya perselingkuhan seorang istri dengan lakilaki lain). Muncullah sebuah permasalahan atau dendam antara suami terhadap laki-laki pengganggu isterinya.

2. Bagian 1

Pada Bagian 1, akan divisualkan dengan apagar atau bisa disebut dengan menjaga dan melindungi dirinya dengan cara bertapa atau melakukannya sendiri, atau juga meminta bantuan orang lain yang biasa disebut guru yang akan diisi dengan ilmu kekebalan.

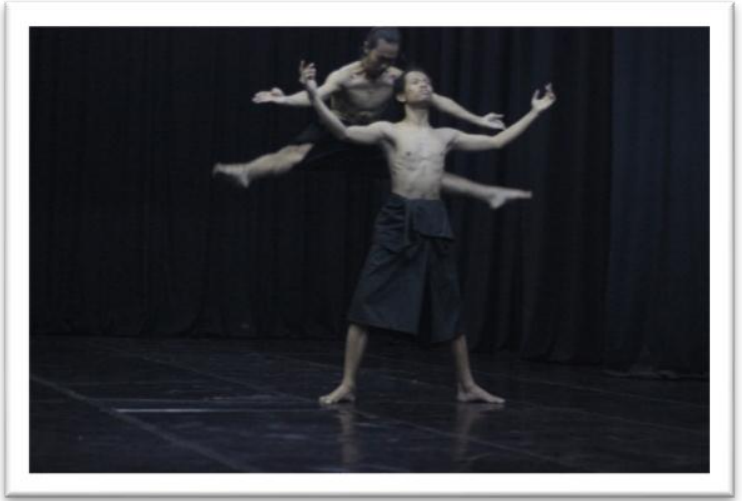

Gambar 11: Pose gerak melompat kendali pasrah

(Foto: Bagus Mahendra, 2020)

3. Bagian 2

Pada bagian 2, penerapan mengasah celurit, lalu mencobanya dengan menerapan kekebalan tubuh yang sudah diisi dengan ilmu kekebalan. Pada penciptaan karya tari ini akan lebih tertuang bagaimana cara melatih carok/silat dengan tarungnya sehingga persiapan kemampuan diri untuk terjadinya pertarungan atau carok di medan perang akan menjadi maksimal. Bagian kedua ini dilakukan oleh 1 penari putra, motif gerak yang digunakan atau dipilih adalah susunan dari gerak-gerak yang sangat dinamis. Motif gerak ini mengidentifikasikan rasa, kekuatan, dan energi yang sangat besar, selayaknya 
orang yang akan mempersiapkan diri di medan pertarungan. Lalu senjata atau properti yang digunakan berupa celurit akan dicoba ke bambu untuk menguji tingkat ketajamannya, jika celurit itu ditebaskan atau dihantamkan ke bambu langsung terpotong menjadi dua bagian dan sangat rapi, halus, dan sangat rata, maka akan menunjukkan bahwa celurit itu sangat tajam dan siap digunakan dalam medan perang atau carok. Begitu sebaliknya, jika celurit itu ditebaskan atau dihantamkan ke bambu terpotong tidak beraturan atau menjadi beberapa bagian dengan hasil tidak rapi, bergerigi atau berserabut, maka celurit tersebut tidak tajam dan perlu pengasahan kembali. Pada bagian ini akan lebih fokus pada penajaman atau mempertajam celurit dan kekuatan energi tubuh seseorang yang menyatu dengan senjata yang ia miliki, dan akan ditunjukkan oleh 1 tebasan pada bambu tersebut yang menjadi 2 potong dengan hasil yang sangat rapi, hasilnya halus, dan sangat rata.

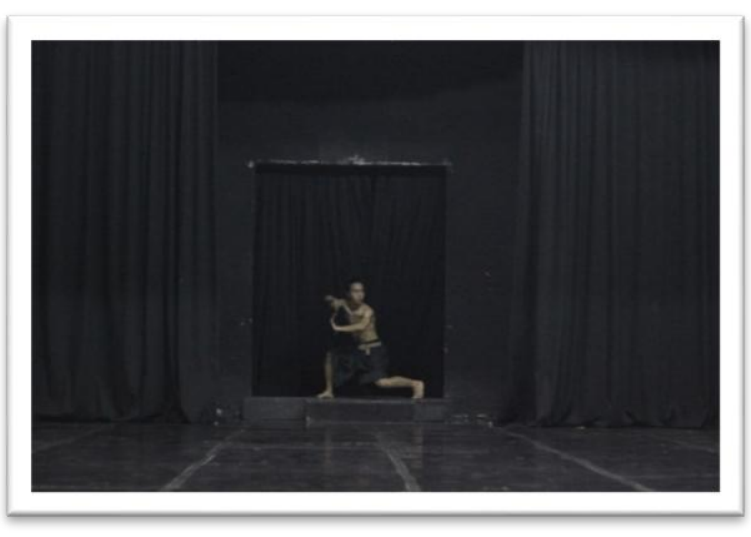

Gambar 16: Pose gerak siap untuk nyreweng kaki ditekuk

(Foto: Bagus Mahendra, 2020)

\section{Bagian 3 (Klimaks)}

Pada Bagian 3 (Klimaks), terjadi saling tantang menantang antara pihak suami dan orang ketiga sebelum terjadinya carok. Lalu, dilanjutkan dengan adanya sebuah konflik sehingga lahir pertarungan atau pertikaian yang biasa disebut carok. Pada bagian ini lebih menggunakan motif gerak dasar silat yang sudah ditransformasikan kedalam bentuk gerak tari yang sudah diperindah, dengan ditambah aksi dan beberapa gerak lain sehingga menciptakan sebuah dinamika yang sangat tinggi pada bagian ini dengan menggunakan properti celurit. Gerak ini akan divisualkan oleh dua orang penari putra dengan bertarung secara nyata atau carok dengan utuh, dengan antraktif dan dinamis yang didukung oleh pembawaan emosi dan mimik dua orang penari. Setelah itu, kedua penari putera 
mengambil dua celurit, dan satu penari putera akan berada di center dengan didukung lampu spesial light, ketiga penari putera melakukan gerak berlari ke titik-titik tertentu yang akan disertai adanya aksi yang sudah ditetapkan oleh penata sebagai simbol adanya serangan pada penari putera yang berada di tengah (center). Pada bagian ini akan lebih menunjukkan serangan suami kepada pihak yang salah atau orang ketiga secara simbolik.

\section{Ending}

Pada Ending akan ada dampak dan hasil dari sebuah klimaks, yang salah akan tetap kalah. Orang yang menang atau benar, dan yang dilecehkan harga dirinya akan berusaha menjaga dan mempertahankan harga dirinya. Kemenangan suami atau pihak yang benar dalam sebuah pertarungan atau carok, akan diakhiri dengan adanya bekas darah korban atau pihak yang salah menempel di celurit suami akan dijilat sebagai tanda kepuasan. Lalu menaruh celurit di atas dada korban sebagai simbolis kemenangan dan dialah pembunuhnya.

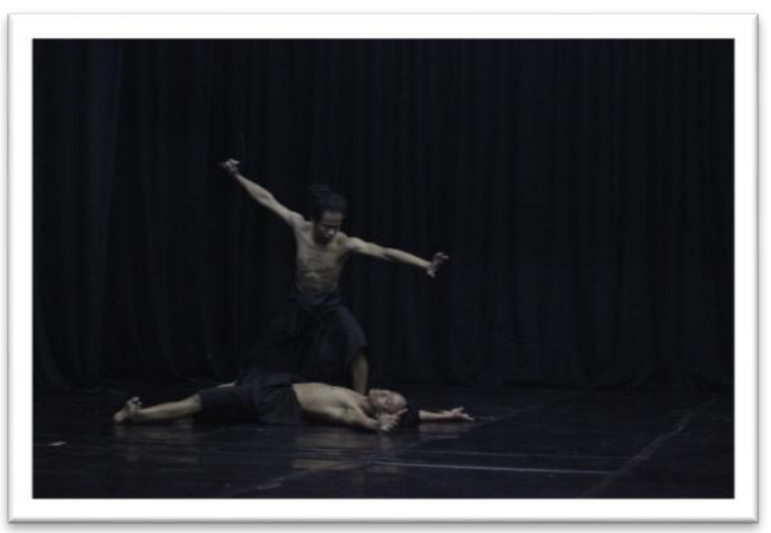

Gambar 22: Pose gerak sereweng maju - jatuh terkapar

(Foto: Bagus Mahendra, 2020) 


\section{PENUTUP}

Karya Tari Abhillani Abha' adalah sebuah karya yang bersumber dari kebiasaan masyarakat Madura khususnya di daerah Bangkalan, dengan kasus carok yang dilakukan oleh laki-laki untuk melindungi atau mempertahankan harga dirinya. Secara signifikan carok dijadikan sumber materi dramatik dan sumber materi artistik pada penciptaan karya tari ini.

Pada penciptaan karya tari ini, menggunakan Metode Konstruksi I - V yang digagas atau disampaikan oleh Jacqueline Smith berjudul Dance Compotitions: A Practical Guide for Teacher (1976), diterjemahkan oleh Ben Suharto, Komposisi Tari: Sebuah Petunjuk Praktis Bagi Guru (1985). Penciptaan karya menggunakan dua rangsang, berupa rangsang visual dan rangsang kinestetik yang sangat mendukung proses penciptaan karya tari. Tema atau permasalahan pokok yang disampaikan dalam karya, yaitu: pelecehan.

Karya tari ini menggunakan Tipe tari dramatik diikuti permainan motif gerak dalam konsep ruang, waktu, dan tenaga akan mewujudkan motif gerak yang unik dan spesifik. Pengembangan motif gerak dalam sebuah koreografi ini menggunakan properti celurit untuk media. Melalui gerak-gerak dasar Tari Madura dan silat, serta gerak dasar
Tari Jawatimuran, dan disertai gerak-gerak simbolis, diungkapkan ke dalam bentuk karya tari. Proses koreografi ini didukung dengan adanya 4 unsur atau tahap yang saling berkaitan, yaitu eksplorasi, improvisasi, komposisi, dan evaluasi. Empat unsur ini bisa dilakukan secara acak atau tumpang tindih, tergantung kebutuhan penata dengan unsur apa terlebih dahulu yang digunakan, sehingga diikuti unsur lain yang saling berkaitan. 
JOGED: Jurnal Seni Tari

p-ISSN 1858-3989 | e-ISSN 2655-3171

\section{DAFTAR SUMBER ACUAN}

\section{A. Sumber Tertulis}

Guntur. 2016. Metode Penelitian Artistik. Yogyakarta: ISI Press.

Hadi, Y. Sumandiyo. 2003. Aspekaspek Dasar Koreografi Kelompok.

Yogyakarta: Elkaphi.

Hadi, Y. Sumandiyo. 2007. Kajian Tari Teks dan Konteks. Yogyakarta: Pustaka Book Publisher.

Hadi, Y. Sumandiyo. 2014. Koreografi Bentuk-Teknik-Isi. Yogyakarta:

Cipta Media.

Hadi, Y. Sumandiyo. 2017. Koreografi Ruang Proscenium. Yogyakarta:

Cipta Media.

Hastanto, Sri. 2011. Kajian Musik Nusantara. Surakarta: ISI Press.

Hawkins, Alma M. 1964. Creating Through Dance. New Jersey: Printice Hall, Inc Lubart. T.I.1994.

Creativity. New York: Academi.

Hidajat, Robby. 2016. Teknik Tari Tradisi. Malang: Universitas Negeri
ABHILLANI ABHA': KOREOGRAFI YANG TERILHAMI DARI NILAI HARGA DIRI DI MADURA

Malang.

Kusmayati, A.M Hermin. 2000. Arakarakan Seni Pertunjukan Dalam

Upacara Tradisional di Madura. Yogyakarta: Yayasan untuk Indonesia.

Langer, Suzanne K. 2006. Diterjemahkan oleh FX. Widaryanto.

Problematika Seni. Bandung:

Sunan Ambu Press STSI Bandung.

Martono, Hendro. 2008. Sekelumit Ruang Pentas Modern dan Tradisi.

Yogyakarta: Cipta Media.

Martono, Hendro. 2010. Mengenal Tata Cahaya Seni Pertunjukan.

Yogyakarta: Cipta Media.

Martono, Hendro. 2015. Ruang Pertunjukan dan Berkesenian. Yogyakarta: Cipta Media.

Meri, La. 1975. Dance Composition The Basic Element. Diterjemahkan oleh Soedarsono. Yogyakarta: ASTI Yogyakarta. 
Murgiyanto, Sal. 1985. Pengetahuan Elementer Tari dan Politik

$$
\text { Kebudayaan. Jakarta: }
$$

Departemen P\&K.

Murgiyanto, Sal. 1992. Koreografi.

Jakarta: Pusat Pembukuan

Departemen Pendidikan dan

Kebudayaan.

Nuraini, Indah. 2011. Tata Rias \& Busana Wayang Orang Gaya Surakarta.Yogyakarta: Badan Penerbit ISI Yogyakarta.

Smith, Jacqueline diterjemahkan oleh Ben Suharto S. 1985. Komposisi Tari Sebuah Petunjuk Praktis Bagi Guru. Yogyakarta: Ikalasti.

Soelarko dan S. Ilmi. 2007. Kesenian Rakyat Gandrung dari Banyuwangi.

Jakarta: Proyek Media

Kebudayaan Departemen Pendidikan dan

Kebudayaan Jakarta.

Sumaryono. 2007. Jejak dan Problematika Seni Pertunjukan Kita.

Yogyakarta: Parista.
Sumaryono. 2011. Antropologi Tari dalam Perspektif Indonesia.

Yogyakarta: Cipta Media.

Sumaryono. 2014. Karawitan Tari Suatu Analsis Tata Hubungan.

Yogyakarta: Cipta Media.

Sumardjo, Jakob. 2006. Estetika Paradoks. Bandung: STSI Bandung.

Task Force Panduan Tugas Akhir Jurusan Tari. 2015. Panduan Tugas Akhir Skripsi dan Skripsi Karya Tari. Yogyakarta: Jurusan Tari Fakultas Seni Pertunjukan Institut Seni Indonesia Yogyakarta.

Wiyata, A Latief. 2002. Carok Konflik Kekerasan dan Harga Diri Orang Madura. Yogyakarta: LkiS.

Yudiaryani, dkk. 2017. Karya Cipta Seni Pertunjukan. Yogyakarta: JB Publisher. 
B. Sumber Lisan

Sudarsono, 54 tahun, Perumahan

Pondok Halim no. C5 Kabupaten

Bangkalan.

R.B Zaini Malik, S.Pd, 60 tahun, Lamongan Jawa Timur.

Sugiono, 51 tahun, Desa Tokelan

Kecamatan Panji Kabupaten

Situbondo.

C. Sumber Seni Pertunjukan

Karya Uji Koreografi Mandiri oleh

Fatmawati Sugiono Putri tahun 2019.

Karya Tari Kayangan Api Parade Tari

Nusantara tahun 2015.

\section{Sumber Webtografi}

"Madura Jaddih" adalah bentuk Seni Pertunjukan Silat atau Kesenian Silat Carok di Madura, diunggah pada tahun 2019 oleh Eddy Dellahoya.

Tsbb (Tendang Slewa Sinar Bringen) adalah gerak dasar Seni Pertunjukan

Silat atau Kesenian Silat Carok dilakukan secara tunggal di Madura, diunggah pada tahun 2018 oleh Ratu Ningsih Ningsih.

OM Putra Buana (Rancap Madura) adalah bentuk Kesenian Carok yanga ada di Madura, diunggah pada tahun 2017 oleh Efendi Official TV. 